\title{
The Evolution of Biological Societies in Alberta
}

\author{
Lu CARByn ${ }^{1}$, Robin LeECH ${ }^{2,4}$, and Gary Ash ${ }^{3,4}$ \\ ${ }^{1}$ Department of Renewable Resources, University of Alberta, Edmonton, Alberta T6G 2H1 Canada; and Canadian Wildlife \\ Service, Twin Atria Building, 200 - 4999 - 98 Avenue NW, Edmonton, Alberta T6B 2X3 Canada \\ ${ }^{2}$ Research Associate, Royal Alberta Museum, 12845-102 Avenue NW, Edmonton Alberta T5N 0M6 Canada \\ ${ }^{3}$ Golder Associates Ltd., \#300, 10525-170 Street NW, Edmonton, Alberta T5P 4W2 Canada \\ ${ }^{4}$ P.Biol. [Professional Biologist]
}

Carbyn, Lu, Robin Leech, and Gary Ash. 2010. The evolution of biological societies in Alberta. Canadian Field-Naturalist 124(4): 321-329.

At present, four organizations serve biologists in Alberta: The Alberta Chapter of the Wildlife Society (ACTWS), The Alberta Native Plants Council (ANPC), The Alberta Society of Professional Biologists (ASPB), and The Canadian Society of Environmental Biologists (CSEB). Only the ASPB is a professional regulatory organization, two of the others (CSEB and ACTWS) have their origins in the Canadian Society of Wildlife and Fisheries Biologists (CSWFB) while ANPC is a non-regulatory society with independent origin. A fifth organization, the Canadian Chapter of Society for Conservation Biology, is being organized through initiatives resulting from the $24^{\text {th }}$ International Congress for Conservation Biology, held in Edmonton in July 2010 . Its role in Canada is not yet defined.The first biological society to function in Alberta was a chapter of The Canadian Society of Wildlife and Fisheries Biologists (CSWFB). After 10 years this organization morphed into the CSEB when the hopes of creating a professional status faded. This change forced the CSPB towards forming a professional voice on resource use, and towards a communication medium for biological resource management. Biological consulting firms proliferated in the late 1960s and early 1970s, coinciding with provincial and federal governments forming departments of the environment. Pressures from these events created a perceived need by some biologists for a self-regulating, professional organization, which comes under provincial jurisdiction. To this end, the Alberta Society of Professional Biologists (ASPB) formed in 1975, and in 1991 received its Professional Biologist title status (P.Biol.) for members under the Societies Act of Alberta. The Alberta Chapter of The Wildlife Society (ACTWS) was formed in 1989; its focus was on research, science and wildlife management.

Key Words: Biological Societies, Alberta Chapter of the Wildlife Society (ACTWS), The Alberta Native Plants Council (ANPC); The Alberta Society of Professional Biologists (ASPB), and The Canadian Society of Environmental Biologists (CSEB), Alberta.

On the occasion of the $22^{\text {nd }}$ anniversary of The Alberta Chapter of The Wildlife Society (established in 1989), it is worthwhile to reflect on its origins. The parent society - The Wildlife Society - has had a much longer history with its formation in the United States in 1937. North American biologists, mainly wildlife and fisheries biologists, from both Canada and the United States, had formed a professional bond early its history of development. Much of the leadership came from the Americans, although numerous Canadians also served in various executive positions from time to time. The Alberta Chapter of The Wildlife Society was an offshoot of the parent organization. It had its origins in the diverging interests of biologists with different agendas and differing perspectives on professionalism. To better understand that path, it is necessary to look at the bigger picture.

Currently there are four organizations that specifically serve biologists in Alberta. These are the Canadian Society of Environmental Biologists (CSEB), The Alberta Society of Professional Biologists (ASPB), The Alberta Chapter of The Wildlife Society (ACTWS), and the Alberta Native Plants Council (ANPC).

In addition to specific biological societies, there are a number of conservation societies in Alberta that serve specific functions with broad based support from biologists. Some of the larger organizations are AWA (Al- berta Wilderness Society); FAN (Federation of Alberta Naturalists - recently changed its name to NA - Nature Alberta); ALMS (Alberta Lake Management Society); CPAWS (Canadian Parks and Wilderness Society); Alberta Lepidopterist's Guild; Calgary Zoological Society; and the Soil and Water Conservation Society.

The CSWFB was established in 1958 and was a Canada-wide organization. Membership dues in 1967 were $\$ 7.00$ for regular members and $\$ 1.00$ for students. The pan-Canadian Society consisted of six regional chapters (Maritimes, Quebec, Ontario, Prairie Provinces, British Columbia and the Territories). The membership was small but relatively active, and there was considerable cohesion countrywide. Despite the absence of computers, fax machines and photocopy machines, communication among members was very effective. The society had a strong traditional base in the classical disciplines of wildlife and fisheries biology. Its members came from government agencies and universities. There were few, if any, environmental consultants active at the time.

The founding members of CSWFB stated that the aims of the Society were "To establish and maintain the highest possible professional standards in wildlife and fisheries research and management, and to develop all phases of wildlife and fishery management along sound lines in relation to proper land use and in accordance with the best interests in the community." 
Consultants burst onto the scene in the late 1960s and early 1970s. It was also a time that federal and provincial governments began to establish departments of the environment, and laws were enacted to cover environment and resource protection.

With the emergence of laws protecting the environment, the growth of private initiatives and environmental consultants was inevitable. This brought new, evolutionary initiatives to the forefront. The once closeknit Canadian Society of Wildlife and Fisheries Biologist began to fall apart in the late 1960s. It was noted in 1968 that the "decrease in growth of the society, its failure to attract provincial and federal resource biologists and the gradual evolution of the society away from one seeking to create professional status, to one attempting to providing a professional voice, on topics of resource use and provide communication on these and other topics, between Canadian professional resource biologists, was discussed" (Canadian Wildlife and Fisheries Newsletter Bulletin 25(1)).

In immediate terms, the name of CSWFB was changed to the Canadian Society of Environmental Biologists (CSEB), and that was only the beginning of a process that led to the formation of other societies. The old Society of Canadian Wildlife and Fisheries Biologists was clearly in a crisis mode. This was an unfortunate circumstance since it served wildlife and fisheries biologists well, from east to west and south to north. The old organization (CSWFB) adopted a new constitution and was renamed as the Canadian Society of Environmental Biologists (CSEB) in recognition of the broader scope of practice of biologists in Canada. This change did not satisfy or accommodate all biologists in Alberta.

Much debate and considerable turmoil existed in the different orientations within the professional community. Chief architects at the time, who prompted change and demanded a more structured professional group, were government administrators and individuals in newly established consulting firms. Others were not happy with a change from classical wildlife and fisheries orientation to a "watered down" environmental label. These were the more conservative elements among the professionals. Nevertheless, the CSEB survived, but only as a much smaller national organization with generally weaker provincial chapters.

Two societies, the ASPB and ACTWS, staked out their claims for action in the provincial scene. In this regard, Alberta became a leader on the national scene. So how was that possible? In reality, it was not at the expense of CSEB, an organization that proved to have a remarkable level of survival. That was possible only because of some dedicated individuals who volunteered their time and resources to a cause they strongly believed in.

Today the CSEB has a membership of over 200 biologists from coast to coast in Canada. It has sponsored numerous symposia on a variety of national issues. A list of publications resulting from these symposia is provided in Appendix A. The society also publishes a quarterly Newsletter/Bulletin, which includes regional news of interest to biologists, biological articles submitted by its members, and other information that would be of interest to environmental biologists. In more recent times all the CSEB symposia publications were made available in digital format only.

Provincial organizations within CSEB are quite variable and, generally, not as strong as the national organization. CSEB membership ranges broadly within the disciplines of environmental biology including fisheries and wildlife biology, forestry, environmental toxicology, limnology, plant science and zoology. For more details visit the website: http://www.cseb-scbe.org. With these changing trends, there were also competing visions of what professional organizations should be about.

In the early 1970 s, the struggle for influence and membership between the different organizations serving biologist was very pronounced and resulted in heated debates. On the one hand, we had those who believed in environmentally oriented actions. They urged biologists to speak up on environmental issues. Principal proponents of this view were University of Alberta and University of Calgary professors, most notably Drs David Boag, Bill Fuller, Tim Myres and Joe Nelson.

Another group felt that professional biologists should form a "society" to protect professionalism and to establish an organization with a prime focus: to evolve as a self-regulating body in Alberta. Such a society would be committed to promoting excellence in the practice of biology. The society that evolved out of this initiative was The Alberta Society of Professional Biologists (ASPB) with a 2010 membership approaching 1000 biologists (Table 1) (actual active memberships in November 2010 stood at 894). The enthusiastic province-wide participation in this membership is remarkable considering the high annual membership dues.

The principal leader in the movement towards establishing a provincially incorporated society, a professional regulatory organization, equivalent to those of the engineers, agrologists, veterinarians and others, was the then Alberta Director of Wildlife and Fisheries, Dr. Stu Smith. Dr. Robin Leech, P.Biol., served as the first Secretary for the ASPB, working directly with the late Stu Smith, P.Biol., Don Dabbs, P.Ag., P.Biol., and others who helped to register the ASPB as a legal society in 1975 . The ASPB was registered as a professional regulatory organization in 1991 under the Professional and Occupational Associations Registration Act (POARA) of Alberta, permitting its members to have the exclusive right to title of Professional Biologist, or P.Biol., but not with exclusive right of practice (as with P.Eng.). 
The ASPB publications are listed in Appendix B.

On the provincial scene, the ASPB has grown at a remarkable rate and has established a very effective society with a well-funded infrastructure. The website is www.aspb.ab.ca, and direct contact can be made through http://pbiol@aspb.ab.ca. There are major difference between the ASPB and CSEB. The main one is that the ASPB is a provincially regulated organization (PRO) with legal status and exclusive right to title (Professional Biologist or P.Biol.) for its members, whereas the CSEB is an interprovincial organization with no provincial regulation, legal status or title for its members.

The objectives of the ASPB are as follows:

1. To promote high standards of professional competence and ethics in its membership and in biologists at large;

2. To provide a mechanism through which the public of Alberta will be assured of the highest possible standards in the practice of biology;

3. To provide a common ground for Professional Biologists in all disciplines to meet and exchange views;

4. To promote education in the field of biology; and

5. To provide a recognized voice for Professional Biologists in Alberta.

Typically, the ASPB does not comment on controversial environmental issues, but rather restricts its involvement to professionalism, education and self-regulation of its members.

The 2011 membership fee for the ASPB is $\$ 250$ for a full member, Biologist-in-Training (BIT) fee is $\$ 50$. Associated Biologist fee is $\$ 50$, and Student fee is $\$ 25$. Also, there are Honorary Biologist and Temporarily Withdrawn Biologist categories.

To join the ASPB, one needs a minimum of a BSc in biology from a recognized institution, and a minimum of 3 years of recognized professional experience. ASPB provides mentoring programs for new members, job market contacts, connection to specific specialists, a practice review committee, a code of ethics, a monthly eBulletin and a three-times-per-year newsletter, BIOS. As part of the Continuing Competency Program, Edmonton and Calgary have noon or evening meetings with specialist speakers. The Annual General Meeting is held in either Calgary, Red Deer or Edmonton in concert with the Annual ASPB Conference.

ASPB has internal awards to its members. Submitted published papers and/or reports are assessed and winners receive the Peggy Thompson Awards. Another award is the J. Dewey Soper Award, which can be awarded to any Alberta biologist who has made major contributions and accomplishments (research and published results), and whose work makes a connection to the next generation of biologists.

ASPB offers scholarships to biologists. The Dr J. Allan Birdsall, P.Biol. Scholarship is for \$10,000 annually. Each of the three universities in Alberta (University of Alberta, University of Calgary and the University of Lethbridge) has an ASPB Endowed Scholarship
Award of $\$ 2500$ for graduate students in the fields of biology. These are awarded annually.

On 1 April 2006, the governments of British Columbia and Alberta entered into an agreement where professionals and trades people could move from one province to the other without hindrance. This was called the Trade, Investment and Labour Mobility Agreement (TILMA). TILMA came into effect on 1 April 2009. A member in the ASPB need only show credentials and present a letter confirming good standing with ASPB, and pay the membership fee, to become a Registered Professional Biologist (R.P.Bio.) in British Columbia. The person could either maintain both professional memberships, or give one up, depending on where he or she is living and working. Membership in the Association of Professional Biologists of British Columbia (APBBC) requires that one must first be a member in good standing of the College of Applied Biology (CAB-BC): http://www.cab-bc.org. Professional Biologists in British Columbia are governed by the CAB. TILMA has caused an increase in the memberships of the ASPB and the CAB-BC, as there are many professional biologists who work regularly in both provinces. In late 2008, Lloyd Saul of ERIN Consultants Ltd, Regina, and some of his staff became interested in forming a Professional Biologists organization in Saskatchewan. Saul informs us (RL) that he has been working with the other registered professional organizations (stakeholders), but especially the Professional Agrologists, in Saskatchewan towards forming a Saskatchewan Society of Professional Biologists

And further east, in Winnipeg, Manitoba, an ASPB member, Shirley Bartz, P.Biol., Marlene Gifford, P.Biol., and previously, Don Harron, P.Biol., in Stantec in Winnipeg, have been attempting to set up a Professional Biologists organization. They, too, have been working with foresters and agrologists. Don registered an official name, Manitoba Society of Professional Biologists (MSPB). Marlene Gifford, P.Biol., and Shirley Bartz, P.Biol., are now on their own, as Don has returned to Alberta.

The aims and objectives of the modern Canadian Society of Environmental Biologists is to further the conservation of Canadian natural resources, to ensure the prudent management of these resources so as to minimize environmental effects, and to maintain high professional standards in education, research and management related to natural resources and the environment. The Canada-wide membership changes over the years 1973 to 2010 are presented in Table 2 and Figure 1. The distribution of the membership across the different regions in Canada in 2010 is listed in Table 3. The trend in the Canadian membership in the CSEB from 1973 to 2010 is given in Figure 1.

Over the years, the CSEB has been active in assessing and commenting on administrative and legislative polices and program, often controversial, which may 
TABLE 1. ASPB (Alberta Society of Professional Biologists) Membership Trends

\begin{tabular}{|c|c|c|c|c|c|}
\hline Year & Regular & Biologist in Training & Student & Honorary/ Retired/ Inactive & Total \\
\hline 1988 & 228 & 5 & 6 & 2 & 241 \\
\hline 1989 & 222 & 4 & 6 & 2 & 234 \\
\hline 1990 & 221 & 1 & 0 & 2 & 224 \\
\hline 1991 & 249 & 4 & 5 & 2 & 260 \\
\hline 1992 & 243 & 8 & 12 & 2 & 265 \\
\hline 1993 & 255 & 5 & 15 & 2 & 277 \\
\hline 1994 & 264 & 7 & 21 & 3 & 295 \\
\hline 1995 & 281 & 12 & 28 & 3 & 324 \\
\hline 1996 & 295 & 10 & 39 & 3 & 347 \\
\hline 1997 & 305 & 18 & 43 & 23 & 389 \\
\hline 1998 & 316 & 20 & 30 & 23 & 389 \\
\hline 1999 & 333 & 24 & 28 & 27 & 412 \\
\hline 2000 & 347 & 27 & 26 & 27 & 427 \\
\hline 2001 & 375 & 35 & 14 & 14 & 438 \\
\hline 2002 & 407 & 43 & 7 & 45 & 502 \\
\hline 2003 & 438 & 52 & 5 & 46 & 541 \\
\hline 2004 & 465 & 53 & 5 & 28 & 551 \\
\hline 2005 & 483 & 60 & 7 & 35 & 585 \\
\hline 2006 & 510 & 70 & 9 & 38 & 627 \\
\hline 2007 & 564 & 108 & 18 & 38 & 728 \\
\hline 2008 & 624 & 119 & 20 & 41 & 804 \\
\hline 2009 & 699 & 134 & 12 & 42 & 887 \\
\hline 2010 & 725 & 169 & 7 & 49 & 951 \\
\hline
\end{tabular}

Note: Membership data since1992 were obtained from POARA Annual Reports. Data prior to 1992 were obtained from Board minutes.

Inactive and Retired members were added with Honorary in 1997.

TABLE 2. CSEB (Canadian Society of Environmental Biologists) Alberta Chapter Membership Trends.

\begin{tabular}{|c|c|c|c|c|c|c|}
\hline Year & Compl./ Hon. & Associate & Library & Regular & Student & Total \\
\hline 1987 & & 1 & 3 & 65 & 11 & 80 \\
\hline 1988 & & 1 & 5 & 80 & 18 & 104 \\
\hline 1989 & & & & & & $\mathbf{n} / \mathbf{a}$ \\
\hline 1990 & & 5 & 6 & 93 & 11 & 115 \\
\hline 1991 & & 3 & 7 & 91 & 7 & 108 \\
\hline 1992 & & & 4 & $83 *$ & 5 & 92 \\
\hline 1993 & & & 4 & $86^{*}$ & 14 & 104 \\
\hline 1994 & & & & & & $\mathbf{n} / \mathbf{a}$ \\
\hline 1995 & & 3 & 3 & 66 & 4 & 76 \\
\hline 1996 & & 3 & 3 & 71 & 8 & 85 \\
\hline 1997 & & 3 & 3 & 63 & 2 & 71 \\
\hline 1998 & & 1 & 2 & 74 & 3 & 80 \\
\hline 1999 & & 2 & & 55 & 1 & 58 \\
\hline 2000 & & & & & & $\mathbf{n} / \mathbf{a}$ \\
\hline 2001 & 1 & & 4 & 58 & 2 & 65 \\
\hline 2002 & & & & & & 0 \\
\hline 2003 & & 1 & 5 & 64 & 1 & 71 \\
\hline 2004 & & & 4 & 44 & 2 & 50 \\
\hline 2005 & & & & & & 0 \\
\hline 2006 & & 1 & 3 & 49 & 3 & 56 \\
\hline 2007 & 1 & & 4 & 46 & 2 & 53 \\
\hline 2008 & 1 & & 4 & 40 & 4 & 49 \\
\hline 2009 & & & & & & o \\
\hline $2010 *$ & 1 & 1 & 4 & 64 & 8 & 78 \\
\hline
\end{tabular}

* 2010 membership numbers current to October 2010 


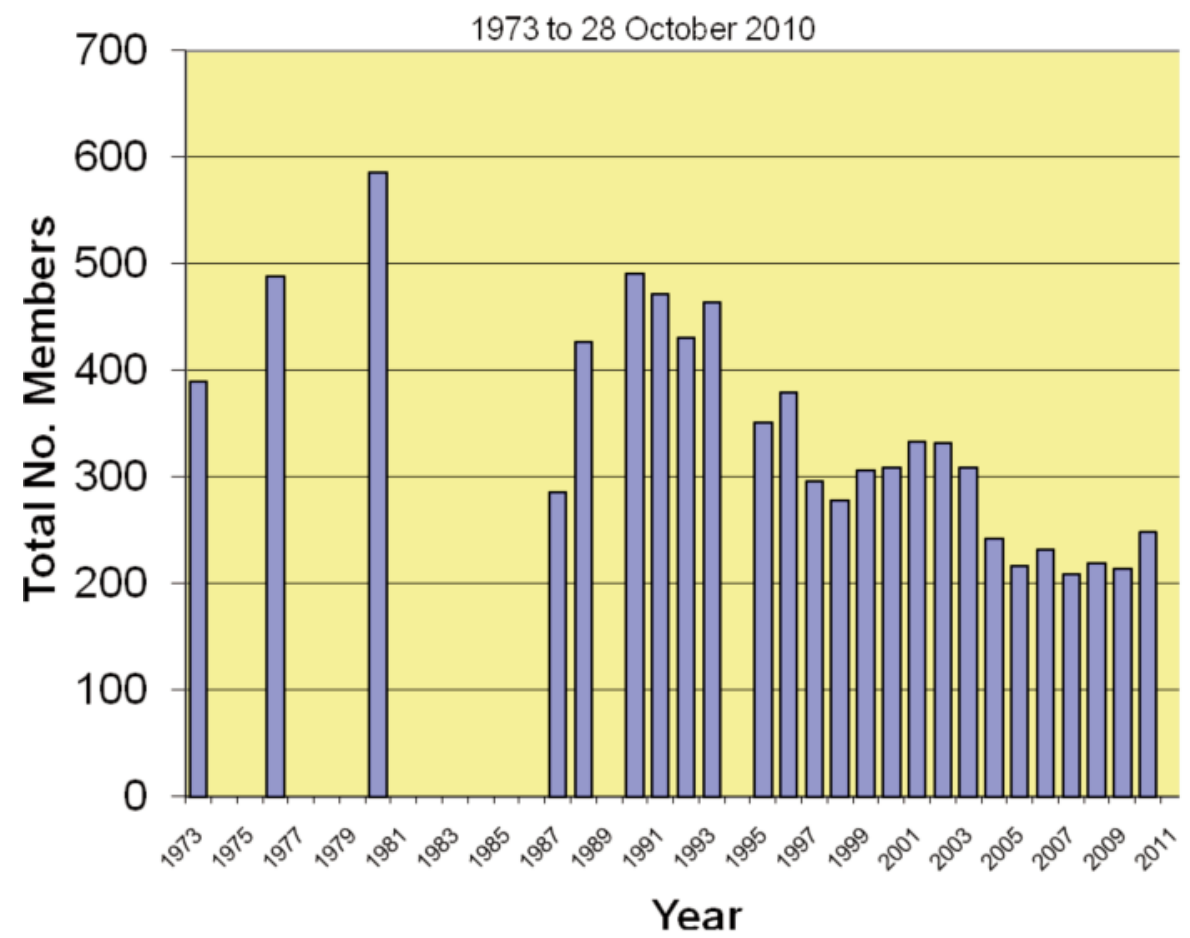

FIGURE 1. CSEB (Canadian Society of Environmental Biologists). Membership by Year (1973 to 2010).

TABLE 3. CSEB (Canadian Society of Environmental Biologists) Membership by Region and Category up to 28 October 2010

\begin{tabular}{|c|c|c|c|c|c|c|}
\hline Region & Complementary/Honorary & Associate & Library & Regular & Student & Total \\
\hline 1 Atlantic & 2 & 4 & 2 & 17 & 1 & 26 \\
\hline 2 Quebec & & 1 & & 15 & & 16 \\
\hline 3 Ontario & 3 & 3 & 3 & 40 & 3 & 52 \\
\hline 4 Manitoba & 1 & & & 4 & & 5 \\
\hline 5 Sask. & 1 & & & 17 & 1 & 19 \\
\hline 6 Alberta & 1 & 1 & 4 & 64 & 8 & 78 \\
\hline $7 \mathrm{BC}$ & 2 & 1 & & 31 & 2 & 36 \\
\hline 8 Territories & & 1 & & 12 & & 13 \\
\hline 9 USA & 1 & & 1 & & & 2 \\
\hline 10 Foreign & & & & 1 & & 1 \\
\hline Totals & 11 & 11 & 10 & 201 & 15 & 248 \\
\hline
\end{tabular}

have significant ecological ramifications. Some examples of this includes comments or briefs on the Federal Environmental Protection Act, the Federal Environmental Assessment process, the Federal Green Plan, the Endangered Species Act, the management of nuclear fuel wastes, and the reductions to Environment Canada budgets (including Canadian Wildlife Service).

Some think that CSEB could become a national organization that would serve to unite all professional biologists across Canada, much as the Chemical Institute for Canada (CIC) does for Canadian chemists. Although there have been several initiatives over the years to have CSEB take on the professional regulatory role (i.e., professional society similar to the ASPB), it is realized that the legislation regulating professions falls under provincial regulations, and therefore, cannot be accomplished by a national organization under its current structure.

Both organizations put on workshops and hold symposia, but CSEB lacks the financial stability, and depending on volunteer services and nation-wide scope, has a much more difficult time in serving its members. The difficulty in attracting volunteers, with all of the competing organizations and leisure activities in modern society, has limited the growth of the CSEB. 
Recent developments in a Canada-wide perspective, is the possible formation of a Canadian chapter of the very active, world-wide Society for Conservation Biology (SCB). The possible merger of such an organization with CSEB might be something to be considered as a viable future endeavour. Dr. Colleen Cassady St. Claire has been involved in the initiative to possibly establish the Canadian chapter of the SBC.

The Alberta Chapter of The Wildlife Society (ACTWS) evolved when some Alberta biologists did not see either the CSEB or the ASPB as the answer. Simply put, loyal and traditional Wildlife Biologists from the old Canadian Society of Wildlife and Fisheries Biologists were not entirely happy with CSEB or ASPB at the time, and began to develop a Canadian Branch of a very well-established and functioning North American Society whose international power base was in the United States. Naturally, there were many who joined several organizations.

The Wildlife Society has a total membership of 9347 in November 2010 and by December 2010 had increased to 10200 with 7177 located in the United States (November 2010). The Canadian total for TWS was 366. TWS has an official certification program with prescribed protocol a trademarked wildlife biologist for approval. As of November 2010, 3834 wildlife biologists in the United States held current certificaton while 181 in Canada held current certification, 39 of whom are located in Alberta. In 2010 there were five student Chapters in Canada (University of Alberta, Lethbridge Community College, Lakehead University, University of Northern British Columbia, University of Laval) and four provincial Chapters Canada-wide (British Columbia, Alberta, Manitoba and Ontario).

The Alberta Chapter of The Wildlife Society (ACTWS) and the CSEB have less rigid entrance requirements and much lower annual fees than does the ASPB. ACTWS is very much oriented towards research and management of wildlife resources and wild lands. It retained some of the old CSWFB perspectives, but added many new dimension towards its sphere of involvement. One of the most notable dimensions is the holding of effective annual meetings in the province, and more than any other professional group, has fostered the development of student participation. The society annually has granted the prestigious William Rowan award to an outstanding biologist who has made major contributions to the science and management of wildlife resources. The Chapter in 2010 has a membership of about 250 individuals. In more recent years the husband and wife ecologists Drs Evie Merrill and Mark Boyce, have led the way in Alberta on TWS initiatives. In previous years Drs Margo Pybus and Bill Samuel were very active within ACTWS and continue to participate in its varied activities.

Members are associated with a broad spectrum of disciplines associated with universities, government agencies, consultants, various private organizations and industry. Much of the core membership comes from leadership provided by universities and colleges in the province. A very encouraging aspect of ACTWS is its strong and active University of Alberta branch, in which students provide leadership and professional development.

For the website of the ACTWS youth chapter in Edmonton (the University of Alberta entity) visit http: //www.ualberta.ca/uatctws/. A similar initiative is in place at the Lethbridge Community College.

Independent from the evolution of CSWFB, CSEB and ACTWS was another professional organization, The Alberta Native Plant Council (ANPC), whose membership consists of botanists and those interested in plant conservation in Alberta. The Alberta Native Plant Council was organized as a result of the 1986 Federation of Alberta Naturalists Workshop on "Endangered Plant Species" in the Prairie Provinces. In 1986, the society was formally established as a registered society. The society meets on a regular annual basis, and in 2010 had a membership of about 200 individuals.

Few could have predicted the outcomes of the struggles that existed in the early 1970 s. What is remarkable is the growth and proliferation of both the number of societies and the total population of biologists in the province. From what started as one society with about 12 to 20 members (meeting regularly in private homes in the mid 1960s) to as many as 1500 biologists after 40 years of development. In a larger context there are many more related disciplines with their own professional organizations such as those of foresters, forest technologists, agrologists, limnologists, chemists, fisheries biologists and landscape architects. One estimate places a total of a possible 2500 professional members in Alberta. It is not surprising that a resource rich province, such as Alberta, has been at the forefront in developing biological societies in Canada.

\section{Acknowlegments}

We thank Shauna Prokopchuk and Joy Sager of Managewise, the company that does most of the administrative work for the Alberta Society of Professional Biologists, for quickly providing much needed historical information. Joe Nelson and Bill Wishart provided relevant information that was included in this paper. Shannon Pedersen and Art Rodgers, from The Wildlife Society, provided data that were used in updating figures for the current status of this professional society. Thanks are also given to Shirley Bartz, P.Biol., of Winnipeg, and to Lloyd Saul of ERIN Consulting in Regina, and Don Harron, P.Biol., of Calgary, for providing last-minute information for this article.

Received 18 February 2010

Accepted 19 November 2010 


\section{Appendix A. Publications of the Canadian Society of Environmental Biologists}

Updated to October 2010

Publications may be ordered by payment or invoice to: CSEB National Office, P.O. Box 962, Station F, Toronto, Ontario M4Y 2N9 Canada.

Northcote, Tom. Editor. 2007. Limnology - The publicly unknown science of inland waters: Overviews on some of its important topics. Canadian Society of Environmental Biologists Newsletter/Bulleting 64(1): 1-50. (\$20.00+ $\$ 2.50 \mathrm{~S} \& \mathrm{H})$.

This special publication includes seven papers discussing limnological topics including faecal pollution in inland waters, cumulative effects of climate warming and human demands on freshwater, drinking water treatment, mining development and impacts on aquatic resources in the Canadian North, and forestry and freshwater in Canada.

Canadian Society of Environmental Biologists. 2001. The New Millennium: Can threatened/endangered species recover? Proceedings of the $40^{\text {th }}$ Annual Meeting of the Canadian Society of Environmental Biologists, Vancouver, British Columbia, February 16-17, 2001. 103 pages $(\$ 20.00$ $+\$ 2.50 \mathrm{~S} \& \mathrm{H})$.

The proceedings include papers and abstracts of presentations on the biology and management of threatened and endangered species, as well as CSEB's comments on the Species at Risk Act that were forwarded to the Parliamentary Committee on Environment.

Ryan, P. M., Editor. 1999. Assessment and impacts of megaprojects. Proceedings of the $38^{\text {th }}$ Annual Meeting of the Canadian Society of Environmental Biologists in collaboration with the Newfoundland and Labrador Environment Network, St. John's, Newfoundland. Canada, October 1-3, 1998. Canadian Society of Environmental Biologists. Toronto. $x+233$ pages. $(\$ 25.00+\$ 2.50 \mathrm{~S} \& \mathrm{H})$.

The 1998 CSEB Annual Meeting was designed to constructively review environmental assessment goals, processes, achievements, and failures; particularly as they apply to large-scale projects. Topic areas included assessment processes and their components as well as case studies and critiques. The proceedings consist of 21 invited and contributed papers and participants' formal comments and recommendations pertaining to environmental assessment.

Canadian Society of Environmental Biologists. 1999. Fish and wildlife research and management: applying emerging technologies. Proceedings of the $37^{\text {th }}$ Annual Meeting of the Canadian Society of Environmental Biologists, Edmonton, Alberta, September $28-30,1997.136$ pages. $(\$ 20.00$ $+\$ 2.50 \mathrm{~S} \& \mathrm{H})$.

The proceedings include 12 papers and 22 abstracts of presentations on the use of new technology being used in the field of fish and wildlife research and management. Specific sessions dealt with computer modeling and simulation, use of DNA, and isotopes, use of GIS and GPS, habitat improvement techniques, use of telemetry and acoustics, and biomonitoring.

Epp, Henry T. Editor. 1997. Ecological reclamation in Canada at century's turn. Proceedings of the $35^{\text {th }}$ Annual Meeting of the Canadian Society of Environmental Biologists, Regina, Saskatchewan, September 26-29, 1995. 123 pages. $(\$ 20.00+\$ 2.50 \mathrm{~S} \& \mathrm{H})$.

The meeting theme was ecological reclamation or restoration of land and waters in Canada previously disturbed by human activities. Specific papers included restoration of lands disturbed by mining, road building, urban activities, wetland alteration, irrigation, and river alteration. The proceedings also includes a thematic paper by the editor which explains the fit of this series of papers into the overall conference theme.

Delisle, C. E., and M. A. Bouchard. 1996. Proceedings of the $19^{\text {th }}$ international symposium on wastewater treatment, $8^{\text {th }}$ workshop on drinking water, and $36^{\text {th }}$ annual meeting of the Canadian Society of Environmental Biologists, Montreal, Quebec. November 19-21, 1996. 449 pages. $(\$ 25.00+\$ 2.50 \mathrm{~S} \& \mathrm{H})$.

A collection of 50 full presentations or abstracts on quality, quantity, and treatment of urban, industrial, and agricultural wastewater, goundwater, and drinking water. The book deals with research, design, construction, operation, and management of works as well as technological progress in these specialized fields. Predominantly in French.

Dushenko, W. T., H. E. Poll, and K. Johnston. Editors. 1995. Environmental impact assessment and remediation: towards 2000. Proceedings of the $34^{\text {th }}$ annual meeting of the Canadian Society of Environmental Biologists, Royal Roads Military College, Victoria, British Columbia, June $1-3,1994.192$ pages. $(\$ 30.00+\$ 2.50 \mathrm{~S} \& \mathrm{H})$.

A collection of 19 full formal presentations and $14 \mathrm{ab}-$ stracted poster presentations on environmental criteria, guidelines, legislation, theory, practice, and remediation. The book also contains a 5 page summary of a panel discussion on "Environmental health of the Strait of Georgia/Juan de Fuca Strait - the next Great Lakes?"

Ryan, P. M., Editor. 1993. Managing the environmental impact of offshore oil production. Proceedings of the $32^{\text {nd }}$ annual meeting of the Canadian Society of Environmental Biologists, St. John's, Newfoundland, Canada, April 1-4, 1992. 169 pages $(\$ 25.00)$.

This book contains 18 formal papers dealing with policy, monitoring, and wildlife/fisheries resource protection connected with hydrocarbon development in Canadian and international waters.

Yan, N. D. Editor. 1991. Natural resources: riches or remnants? Proceedings of the 1991 conference of the Canadian Society of Environmental Biologists, Toronto, April $4-5,1991.102$ pages. $(\$ 20.00+\$ 2.50 \mathrm{~S} \& \mathrm{H})$

This book contains 17 formal papers on the status of soils, lakes, forests and wildlife in Canada. It includes descriptions of current attempts to include natural resource values in national accounts, and of the national environmental indicators program.

Delisle, C. E., and M. A. Bouchard. Editors. 1990. Joules in the water: Managing the effects of hydroelectric development. A symposium sponsored by the Canadian Society of Environmental Biologists, Montreal, April 6-7, 1989. Collection Environnement et Geologie, Vol. 9, Universite de Montreal. 650 pages. (Out of Stock).

This proceeding includes 32 papers by authors of various scientific backgrounds from across Canada. Papers focus on two mega-projects in Quebec and Manitoba, although specific 
impacts of numerous other projects from across the country (Ont., B.C., Sask., Alb., N. S., and Nfld.) are examined. The book considers impacts on natural resources as well as socioeconomic impacts of hydroelectric development.

Canadian Society of Environmental Biologists. 1990. Sustainable use of Canada's forests: are we on the right path? A symposium sponsored by the Canadian Society of Environmental Biologists, Kananskis, Alberta, 1990. 158 pages. $(\$ 15.00$ Xerox reprint $+\$ 2.50 \mathrm{~S} \& \mathrm{H})$

Eighteen papers and a panel discussion are featured in this book. Eight speakers from 5 provinces look at the use and management of Canada's timber resources in the first section followed by a session which examines the importance of forests for uses and resources other than timber - birds, wildlife, old-growth ecosystems, and tourism.

Canadian Society of Environmental Biologists and the Alberta Society of Professional Biologists. 1988. Seeking consensus: the public's role in environmental decision making. A symposium sponsored by the Alberta Chapter of the Canadian Society of Environmental Biologists and the Alberta Society of Professional Biologists, Edmonton, Alberta, April 26-27, 1988. 115 pages. (\$14.00 Xerox reprint $+\$ 2.50 \mathrm{~S} \& \mathrm{H})$

This conference examined changes that have occurred in the way the public participates in environmental decision making, the effectiveness of communications in raising public awareness, the use of economics to influence public perception, and the role of the public in influencing environmental decisions in Alberta. Fourteen papers are included.

Sanderson, K. Editor. 1987. Conservation strategies in Canada. Canadian Society of Environmental Biologists Newsletter 44(2). 108 pages. $(\$ 12.00$ Xerox reprint $+\$ 2.50 \mathrm{~S} \& \mathrm{H})$

This book is a special edition of the CSEB Newsletter documenting Canada's attempts to implement the World Conservation Strategies of the International Union for Conservation of Nature and Natural Resources. It contains 15 papers dealing with descriptions of the strategies, and the progress towards implementation by the Canadian Wildlife Federation, the World Wildlife Fund, and the Canadian and Provincial governments.

Powter, C. B. 1987. Reclamation targets for the 1990s. Proceedings of a symposium of the Alberta Society of Professional Biologists, the Canadian Land Reclamation Association, and the Alberta Chapter of the Canadian Society of Environmental Biologists, Edmonton, Alberta, May 4-5, 1987. 118 pages. ( $\$ 14.00$ Xerox reprint $+\$ 2.50 \mathrm{~S} \& \mathrm{H})$.

A collection of 18 papers examining emerging issues in reclamation of industrial sites, wildlife habitat, agricultural soils, and urban landscapes. The book includes the measurement of reclamation success by government, industry, biologists, landscape architects, and the public.
Canadian Society of Environmental Biologists. 1986. Tourism and the environment./Conflict or harmony? A symposium sponsored by the Canadian Society of Environmental Biologists Alberta Chapter, Calgary, Alberta, March 18-19, 1986. 127 pages. (\$14.00 Xerox reprint + $\$ 2.50 \mathrm{~S} \& \mathrm{H})$.

This symposium responded to a growing interest in tourism as a major growth industry. The book contains 18 papers dealing with the role of natural resources in attracting tourists, the maintenance of heavily used attractions, and whether or not use and preservation are natural goals.

Canadian Society of Environmental Biologists. 1985. Economy and ecology: the economics of environmental protection. A symposium sponsored by the Canadian Society of Environmental Biologists Alberta Chapter, Edmonton, Alberta, Feb. 19-20, 1985. 224 pages ( $\$ 18.00$ Xerox reprint $+\$ 2.50 \mathrm{~S} \& \mathrm{H})$.

This book contains 18 papers providing a broad perspective integrating the economy and environment. The topic areas include: Assigning values to environmental things; The economics of pollution and pollution control; Environmental and economic factors affecting decision making, and; Public attitudes towards common property resources.

Canadian Society of Environmental Biologists. 1984. Decision making: the role of environmental information. A symposium sponsored by the Canadian Society of Environmental Biologists Alberta Chapter, Red Deer, Alberta, March 17, 1984. 126 pages (\$12.00 Xerox reprint $+\$ 2.50$ $\mathrm{S} \& \mathrm{H})$.

A collection of nine papers covering: the decision process; case histories and experiences; the public and decision making, and; the role of science in government policy and decision making.

Canadian Society of Environmental Biologists. 1983. Resource management in the eastern slopes. A symposium sponsored by the Canadian Society of Environmental Biologists Alberta Chapter, Red Deer, Alberta, March 19, 1983. 98 pages $(\$ 12.00$ Xerox reprint $+\$ 2.50 \mathrm{~S} \& \mathrm{H})$.

The views of a cross-section of resource users are presented. Featured are an analysis of government policy and planning for Alberta's eastern slopes and a panel discussion on resource interactions and conflicts.

Canadian Society of Environmental Biologists. 1982. Agriculture and the environment. A symposium sponsored by the Canadian Society of Environmental Biologists Alberta Chapter, Red Deer, Alberta, March 6, 1982. 139 pages $(\$ 14.00$ Xerox reprint $+\$ 2.50 \mathrm{~S} \& \mathrm{H})$.

A collection of 12 papers addressing the major issues related to agriculture and the environment including land use conflicts, effects of industrial activities and the impacts of agricultural activities on land and water. 


\section{APPENDIX B - ASPB (Alberta Society of Professional Biologists) publications}

Contact ASPB at www.aspb.ab.ca, or phone 780-434-5765 for price and mailing costs.

2007. Solutions to Ecological Issues in the Oil Sands (in preparation, but will be CD only). Editor: Laurie Hamilton, P.Biol.

2006. Water: Science and Politics. (CD and Hard Copy). Editors: Henry Epp, P.Biol., and Dave Ealey, P.Biol. 282 pages. 2004. Prediction to Practice: Environmental Assessment Follow-up. (CD and Hard Copy). Editors: Henry Epp, P.Biol., and M. Kerry Brewin, P.Biol. 173 pages.

2003. Access Management: Policy to Practice. (Hard Copy only). Editor: Henry Epp, P.Biol. 239 pages.
2000. Cumulative Environmental Effects Management Tools and Approaches. (Hard Copy only). Editor: Alan J. Kennedy, P.Biol. 487 pages.

1994. Cumulative Effects Assessment in Canada - From Concept to Practice. (Hard Copy only). Editor: Alan J. Kennedy, P.Biol. 333 pages.

1986. Native People and Renewable Resource Management. Judith Smith, P.Biol., and Jeffrey Green, P.Biol. 275 pages. 